\title{
Pierre Bourdieu (1930-2002)
}

\section{Reformuleringen af okonomisk teori - forskellen på fornuftige og rationelle forventninger $i \mathrm{det}$ okonomiske felt}

\section{Martin D. Munk}

Pierre Bourdieu har med den efterfølgende artikel "Det økonomiske felt" fra 1997 bidraget til udviklingen af økonomisk sociologi, der i de senere år har været en del fokus på, og som siden Max Weber har taget forskellige retninger. Artiklen om økonomien er en teoretisk forløber til et af Bourdieus sidste større videnskabelige værker, Les structures sociales de l'économie, Paris: Seuil, 2000b (som udkommer på engelsk i løbet af det næste års tid). I denne bog slås tonen an ved at bringe et citat af den engelske filosof og matematiker Bertrand Russell: "While economics is about how people make choice, sociology is about how they don't have any choice to make".

"Det økonomiske felt" er et forsøg på at gennemskrive og analysere økonomien, både som teori og som genstand via begrebsapparatet byggende på habitus, felt og kapital. Artiklen er på den måde en analyse, der bryder med en dominerende handlingsteori inden for både økonomisk teori og sociologisk teori, nemlig Rational Action Theory (RAT). RAT har et rationelt individ i centrum i teorien om rationelle forventninger og handlinger, hvorved analysen er en understregning af, at den bevidsthedsfilosofiske tradition, som RAT har et slægtskab med, har en række modsigelser indbygget. Grundlæggende set påpeger Bourdieu, at det antropologiske syn, som RAT indtager, er dybt problematisk, da det ikke har rod i erfaringen og den virkelige verden. Derimod tager RAT udgangspunkt i en intellektualistisk forforståelse af verden og beskriver kun i bedste fald en sammenhæng mellem en model af virkeligheden og virkeligheden selv (se endvidere Bourdieu 2000a). Det er især via feltbegrebet, at Bourdieu tager livtag med økonomien som genstand. I denne bestræbelse mener jeg, at mulighederne med feltbegrebet udfoldes en tand mere end før, hvor Bourdieu støtter sig til tidligere og nuværende prominente sociologer og økonomer, især amerikanske $(\mathrm{N}$. Fligstein, Ed. Mason, A.D. Chandler, J.S. Duesenberry m.fl.). I analysen vises felters relationer til hinanden ved at undersøge det økonomiske felt, især illustreret ved virksomhedsfelter, hvor konkurrencen mellem virksomheder, institutioner og de agerende bliver meget tydelig. Analysen viser, hvorledes navnligt større virksomheder med megen kapital satser i flere felter på samme tid for at udkonkurrere andre konkurrenter (positioner) eller for blot at bevare den nuværende dominerende position i et givet felt (her kan 
man blot tænke på, som eksempel, større danske virksomheder, der bygger sin magt op gennem tre hovedstrategier, nemlig ved at investere i nye felter, som da A.P. Møller gik ind i dagligvareområdet (Føtex), ved at vedligeholde og opbygge gensidige relationer til staten samt ved at udbygge allerede eksisterende aktiviteter i et givet hovedfelt). Herigennem viser Bourdieu, at et felt ikke blot er et, man kan anvende eller analysere ét ad gangen, men at det faktisk kan være nødvendigt $i$ den samlede analyse at undersøge flere felter og underfelter på én gang.

Først i artiklen bygges analysen op ved hjælp af boligmarkedet som genstand, og senere udfoldes analysen ved at studere de strategier og praktikker, der udspilles i forbindelse med virksomhedsfeltet som arena. Det vises, at køb og salg af boliger faktisk ikke kan begrundes ud fra en mikroøkonomisk teori (MØ), som primært baserer sig på en teori om individuelle valg foretaget af såkaldte ombyttelige elementer, hvori der ikke tages højde for, at disse valg er betinget af strukturelle forhold. Herved understreges det historiske perspektiv (som pointe gennem hele artiklen), idet det fremføres, at "de økonomiske handlingers "subjekt" ikke er den rene bevidsthed uden fortid, som teorien opererer med (MØ), og at den økonomiske beslutning ikke foretages af en isoleret, økonomisk agent, men af et fællesskab, en gruppe, en familie eller en virksomhed, der i sig selv fungerer på samme vis som et felt". I forlængelse heraf påpeger Bourdieu at de enkelte handlinger hænger sammen med reproduktionsstrategier i for eksempel virksomheden, der forsøger at klare sig ikke på markedet - som man plejer at kalde det for, men i et komplekst system af felter, som til dels er relativt autonome, og som dels virker i et dynamisk forhold til og med andre felter. I en given virk- somhed bliver andre kapitalformer vigtige, som finansiel kapital, kommerciel kapital (salgsstyrken), teknologisk kapital og symbolsk kapital etc. Generelt gælder det, at "kræfterne i feltet orienterer de dominerende mod strategier, der har som mål at forøge deres dominans" "...... "men ændringerne inden for et felt er..." hyppigt relateret til ændringer udenfor feltet.

For at vende tilbage til begyndelsen: Med artiklen synes Bourdieu til en vis grad at skrive sig ind i den sociologiske tradition efter Max Weber, der forsøgte at definere den økonomiske handling, også mere generelt set. En ambition, som Bourdieu deler, idet han ved flere lejligheder har forsøgt at skabe en generel teori om praktikkernes økonomi, eller i bund og grund en ny økonomisk teori, der er socialt baseret og ikke baseret på "human capital" og "rationality" i snæver betydning. Det er dog tydeligt, at Bourdieu ikke vil gennemføre dette projekt på baggrund af en metodologisk individualisme og heller ikke på grundlag af en handlingsteori, der ser nytten som det endelige slutpunkt, eller for den sags skyld et snævert defineret mål. Her vægter Bourdieu begrebet habitus, men det pointeres, at habitus er et "økonomiserende handlingsprincip som sikrer en omfangsrig besparelse af beregning og tid, en ellers sjælden handlingsressource", og som derfor er basis for fornuftige handlinger og ikke rationelle handlinger.

\section{Litteratur}

Bourdieu, Pierre 2000a: Pascalian Meditations. Cambridge: Polity Press [1997].

Bourdieu, Pierre 2000b: Les structures sociales de l'économie. Paris: Seuil. 